\title{
Case fatality of Pneumonia: A '5' year retrospective study
}

\section{Jimmy Antony, Celine TM,} Michale Chacko

Department of Community Medicine, M.O.S.C Medical College, Kolenchery, Kerala, India

\section{Address for Correspondence:}

Dr. Jimmy Antony,

Department of Community Medicine, M.O.S.C Medical College, Kolenchery, Ernakulam - 682 311, Kerala, India.

E-mail: anjim2010@rediffmail.com

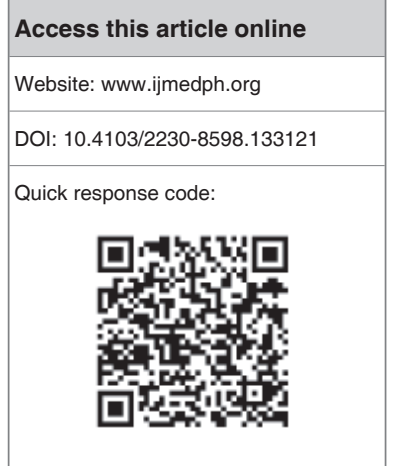

Context: Pneumonia is an inflammatory condition of the lung affecting the alveoli with the infection of microorganisms. Aim: The present study aims to find out the case fatality of pneumonia based on the variables such as age, sex and year. Study Design and Settings: It is a retrospective study of five years conducted in medical college hospital at the Ernakulam district of Kerala State in India. Methods and Materials: The data were collected from the Medical Records department and analyzed by using Microsoft Excel. Statistical Analysis Used: ' $Z$ ' test was applied for finding out the difference in proportions. Result: Out of 5496 pneumonia cases, $3340(60.77 \%)$ were males and $2156(39.22 \%)$ were females. The proportion of males was higher than females. The proportion of pneumonia cases was higher in the low age group (0-5 years) than other age groups. Broncho-pneumonia $(84.95 \%)$ was reported as the most dominant type of infection in the present study. Of 5496 cases, 79 deaths were reported with a case fatality rate of $1.43 \%$. Case fatality rate among males $(1.67 \%)$ was higher than females $(1.06 \%)(P=0.05)$. Case fatality rate of pneumonia in $0-5$ years was $0.11 \%$ and $36.84 \%$ in 85 years and above. Case fatality of pneumonia increased from $0.55 \%$ in 2005 to $4.39 \%$ in 2010. Conclusion: The case infection of pneumonia is higher in low age groups due to associated risk factors while case fatality is higher in old age groups may be due to aging of organ systems and age-associated diseases.

Key words: Age, case fatality, sex, year

\section{INTRODUCTION}

Pneumonia is a leading cause of death worldwide and affecting all the age groups. It is an inflammatory condition of the lung, which affects primarily the microscopic air sacs known as alveoli with the infection of viruses, bacteria or other microorganisms. ${ }^{[1]} \mathrm{It}$ is a very common childhood disease and studies report that case fatality of hospitalized children varies from $8.7 \%$ to $47 \% .{ }^{[2]}$ The 1993 World Development ${ }^{[3]}$ Report produced figures showing that acute respiratory infections caused $30 \%$ of childhood deaths. Recent estimation of $\mathrm{UNICEF}^{[4]}$ show that pneumonia continues to be the number one killer of children around the world-causing $18 \%$ of all child mortality, an estimated 1.3 million child deaths in 2011 alone. World Health Organization reports ${ }^{[5]}$ that it is highly accumulating in SEAR countries because $39.1 \%$ of pneumonia in the world reports from South East Asian Countries. South East Asia Region health report underline this fact by recognizing $70 \%$ of pneumonia deaths occurred in Africa and South East Asia. ${ }^{[3]}$ This study is mainly looking for the case fatality of pneumonia in different age groups in both males and females during a time period of five years from $1^{\text {st }}$ April 2005 to March $31^{\text {st }} 2010$.

\section{MATERIALS AND METHODS}

The data were retrieved from medical records department with the approval of hospital ethical committee. Medical records department follow the guidelines of International Classification of Diseases (ICD)-10 for coding the diseases. The present study aimed to compare the case fatality of pneumonia on the basis of the variables such as age, sex and year. The collected data were processed and analyzed with the Microsoft Excel. 'Z' test was used for comparing the sex wise proportions of age, type of pneumonia and case fatality. Critical ratio $=$ Sex wise difference between proportions of age or type of pneumonia or case fatality/Standard error of difference between proportions of age 
or type of pneumonia or case fatality. Standard error of difference between proportion $=\sqrt{\left(\mathrm{p}^{1} \mathrm{q}^{1} / \mathrm{n}^{1}\right)+\left(\mathrm{p}^{2} \mathrm{q}^{2} / \mathrm{n}^{2}\right)}$. Then ' $P$ ' value is taken from the table with the corresponding value of ' $Z$ ' (critical ratio). If the given ' $P$ ' value is less than or equal to 0.05 means, then there is significant difference between proportions of those two selected groups.

\section{RESULT}

During a time period of 5 years from April $1^{\text {st }}$ of 2005 to March $31^{\text {st }}$ of year 2010, a total of 5496 pneumonia cases were admitted to the study hospital. Out of these 5496 pneumonia cases, 3340 (60.77\%) were males and $2156(39.23 \%)$ were females. The proportion of male cases was higher than female cases. High proportion of the cases were in the low age group ( $0-5$ years) and lower is in older age groups (86 years and above). Of 5496 confirmed cases, 79 deaths reported during this period with a case fatality rate of $1.43 \% ; 1.67 \%$ in males and $1.06 \%$ in females. Age and Sex wise distribution of pneumonia case fatality in both males and females has been specified in the Table 1 . Case fatality of pneumonia is higher in males than females with a significant difference $(P=0.05)$. Sex wise distribution between proportions of case fatality of different age group is not statistically significant. Case fatality rate is zero in 6-14 years $(0 \%)$ and followed by $0-5$ years $(0.11 \%)$ and higher in 86 years and above $(36.84 \%)$. The $0-5$ years age group has significant difference in the case fatality with the age groups higher than 46 years and above $(P<0.0010)$. Out of 5496 cases, $84.95 \%$ were broncho-pneumonia, $8.99 \%$ were lobar pneumonia (J18.1), 5.95\% were unspecified pneumonia (J18.9), 0.04\% was bacterial pneumonia (J15) and $0.02 \%$ was other unspecified pneumonia (J18.8). Sex wise comparison of different types of pneumonia has been depicted in Table 2 and sex wise difference between proportions of different types of pneumonia is also not statistically significant. The case infection based on variables age and sex in different years has been specifically depicted in the Table 3. Pneumonia infection cases are decreasing from $13.13 \%$ in 2005 to $1.65 \%$ in 2010 , while case fatality rate increased from $0.55 \%$ in 2005 to $4.39 \%$ in 2010 as shown in Figures 1 and 2.

\section{DISCUSSION}

Pneumonia is a worldwide public health problem and mortality of this fatal disease is more than the number of deaths caused by measles, malaria and AIDS combined. ${ }^{[6]}$ It reports from each and every corner of the world such as England, ${ }^{[7]}$ United States, ${ }^{[8]}$ Denmark, ${ }^{[9]}$ Netherlands, ${ }^{[10]}$ South Korea ${ }^{[11]}$ and South East Asian Region Countries (SEAR). ${ }^{[12]}$ A study by John Hopkins University ${ }^{[13]}$ certify the fact that India contributes to more than $50 \%$ of the world's pneumonia deaths. In the present study case, fatality rate of pneumonia has increased from $0.55 \%$ to $4.39 \%$ during the study period of five years which extends from 2005 to 2010.

In the present study, case fatality rate of pneumonia is $1.43 \%$. It is lower in low age group (0-5 years) and higher in older age groups. It is $0.11 \%$ in $0-5$ years, 0 in $6-15$ years, $2.32 \%$ in $16-25$ years,
$3.65 \%$ in $26-35$ years, 4.39 in $36-45$ years, $4.72 \%$ in $46-55$ years, $13.97 \%$ in $56-65$ years, $14.85 \%$ in $66-75 \%, 22.07 \%$ in $76-85$ years and $36.84 \%$ in 86 years and above. The $0-5$ years age group has significant difference in the case fatality with the age groups higher than 46 years and above $(P<0.0010)$. Reports show that the case fatality rate of pneumonia in $0-5$ years of the present study is lower than the studies conducted in Thailand $(3.4 \%),{ }^{[14]}$ Bangladesh (4\%), ${ }^{[15]}$ Malawi $(8.7 \%),{ }^{[16]}$ New Delhi $(10.45 \%)^{[17]}$ and Baroda $(11.8 \%)^{[18]}$ on this regard. Pneumonia remains as the leading killer of children

\begin{tabular}{|c|c|c|c|c|}
\hline \multirow[t]{2}{*}{ Age } & \multicolumn{2}{|c|}{ Sex } & \multirow[t]{2}{*}{ Total } & \multirow[t]{2}{*}{$P$ value } \\
\hline & Male & Female & & \\
\hline $0-5$ yrs & 2 & 3 & 5 & - \\
\hline $6-15$ yrs & 0 & 0 & 0 & - \\
\hline $16-25$ yrs & 1 & 1 & 2 & 0.09 \\
\hline $26-35$ yrs & 0 & 3 & 3 & 0.09 \\
\hline $36-45$ yrs & 4 & 0 & 4 & 0.02 \\
\hline $46-55$ yrs & 6 & 0 & 6 & 0.007 \\
\hline $56-65$ & 11 & 2 & 13 & 0.001 \\
\hline $66-75$ & 11 & 4 & 15 & 0.001 \\
\hline $76-85$ & 12 & 5 & 17 & 0.001 \\
\hline 86 and above & 9 & 5 & 14 & 0.001 \\
\hline Total & 56 & 23 & 79 & \\
\hline
\end{tabular}

\begin{tabular}{|c|c|c|c|}
\hline \multirow[t]{2}{*}{ Types of Pneumonia } & \multicolumn{2}{|c|}{ Sex } & \multirow{2}{*}{ Total (\%) } \\
\hline & Males (\%) & Females (\%) & \\
\hline Bacterial Pneumonia (J15) & $2(0.05)$ & 0 & $2(0.04)$ \\
\hline $\begin{array}{l}\text { Pneumonia due to } \\
\text { staphylococcus (J15.2) }\end{array}$ & $1(0.02)$ & $2(0.09)$ & $3(0.05)$ \\
\hline Broncho-Pneumonia (J18.0) & \multicolumn{3}{|c|}{2808 (84.07) 1861 (86.31) 4669 (84.95) } \\
\hline Lobar Pneumonia (J 18.1) & $320(9.58)$ & $174(8.07)$ & $494(8.99)$ \\
\hline $\begin{array}{l}\text { Other Pneumonia, Organism } \\
\text { Unspecified (J 18.8) }\end{array}$ & 0 & $1(0.05)$ & $1(0.02)$ \\
\hline Pneumonia, Unspecified (J18.9) & 209 & $118(5.47)$ & $327(5.95)$ \\
\hline Total & 3340 & 2156 & $5496(100)$ \\
\hline
\end{tabular}

\section{Table 3: Age and Sex wise distribution of} Pneumonia Infection from 2005 to 2010

\begin{tabular}{|c|c|c|c|c|c|c|c|c|c|c|c|c|c|}
\hline \multirow[t]{2}{*}{ Age } & \multicolumn{2}{|c|}{2005} & \multicolumn{2}{|c|}{2006} & \multicolumn{2}{|c|}{2007} & \multicolumn{2}{|c|}{2008} & \multicolumn{2}{|c|}{2009} & \multicolumn{2}{|c|}{2010} & \multirow[t]{2}{*}{ Total } \\
\hline & $M$ & $F$ & $M$ & $F$ & $M$ & $F$ & $M$ & $F$ & $M$ & $F$ & $M$ & $F$ & \\
\hline $0-4$ yrs & 343 & 205 & 369 & 270 & 701 & 447 & 590 & 371 & 509 & 332 & 26 & 26 & 4189 \\
\hline $5-14$ yrs & 45 & 33 & 53 & 29 & 47 & 56 & 111 & 82 & 91 & 57 & 4 & 4 & 612 \\
\hline $15-24$ yrs & 4 & 5 & 5 & 4 & 23 & 21 & 5 & 6 & 5 & 7 & 0 & 1 & 86 \\
\hline $25-34$ yrs & 8 & 5 & 4 & 8 & 12 & 11 & 9 & 6 & 8 & 9 & 2 & 0 & 82 \\
\hline $35-44$ yrs & 8 & 4 & 10 & 7 & 16 & 8 & 12 & 3 & 19 & 3 & 0 & 1 & 91 \\
\hline $45-5$ & 10 & 4 & 18 & 1 & 11 & 9 & 27 & 4 & 27 & 12 & 3 & 1 & 127 \\
\hline $55-64$ yrs & 10 & 5 & 20 & 3 & 9 & 5 & 13 & 5 & 6 & 7 & 6 & 4 & 93 \\
\hline $65-74$ yrs & 12 & 2 & 7 & 3 & 8 & 2 & 15 & 5 & 24 & 16 & 5 & 2 & 101 \\
\hline $75-84$ yrs & 10 & 4 & 11 & 4 & 2 & 3 & 12 & 9 & 12 & 6 & 3 & 1 & 77 \\
\hline $\begin{array}{l}85 y r s \text { and } \\
\text { above }\end{array}$ & 4 & 1 & 5 & 1 & 5 & 11 & 2 & 2 & 3 & 2 & 1 & 1 & 38 \\
\hline Total & 454 & $\angle O C$ & & & & & 16 & 493 & 04 & 51 & 50 & & 19 \\
\hline
\end{tabular}




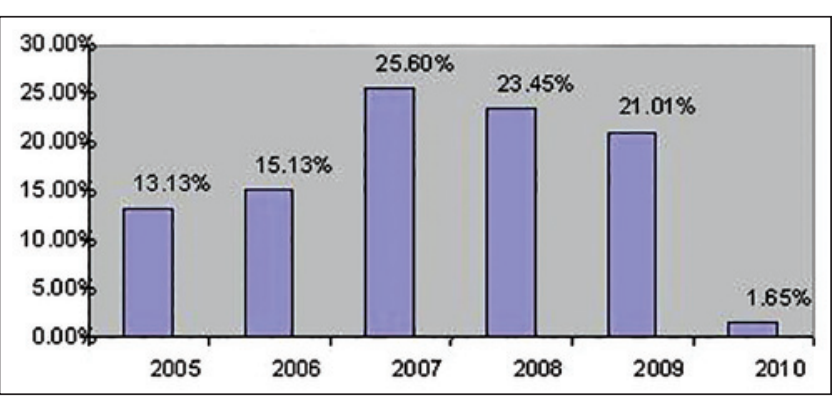

Figure 1: Trend of case infection of pneumonia from 2005 to 2010

globally. World Health Organization Media centre fact sheet on pneumonia ${ }^{[19]}$ and study report on 'Pneumonia behind death of kids under $5^{5[20]}$ unanimously reveals that $18 \%$ of all deaths of children fewer than five years in the world are due to pneumonia. Rudan et al., ${ }^{[21]}$ in their study on Epidemiology and Etiology of childhood pneumonia reveal the fact that $19 \%$ of annual deaths among fewer than five year children in SEAR countries are occurring only due to pneumonia. Singh V et al. ${ }^{[22]}$ certify the fact that $28-34 \%$ of deaths occurring in the age group of 0-5 years in developing countries is due to pneumonia. India tops in global pneumonia deaths of children below five years of age with 3.97 lakh reported in $2010^{[23]}$ and the third annual international vaccine Access Centres (IVAC) pneumonia progress report 2012 underline an increase of $6.7 \%$ from 2008 IVAC data in India. ${ }^{[23]}$ This shows that while the above stated national and international hospital-based studies highlights the high case fatality rate of pneumonia in the age group of 0-5 years, the present study gives a picture of low case fatality compared to other age groups.

In the present study the case fatality rate of pneumonia is higher in the 86 years and above age group and it is $36.84 \%$. The high case fatality of pneumonia in old age group has observed in many hospital-based studies conducted all over the world. Study conducted by Ely EW et al., ${ }^{[24]}$ on Pneumonia in the elderly in a nursing home at Winston-Salem reports, it is the leading cause of death in the old age group. A hospital study by Thomas et al., ${ }^{[25]}$ in Canada reveals a fatality rate of $15 \%$ among adults $<55$ years of age. Another study by Muftan et al. ${ }^{[26]}$ in a hospital at America reports $37.7 \%$ case fatality rate among patients aged above 80 years. According to Jean-Paul Janssens and Karl-Heinz Krause, ${ }^{[27]}$ it is a serious medical problem in old age and high fatality in old age is due to ageing of organ systems and presence of co-morbidity due to age-associated diseases.

In the present study case fatality rate is higher in males than females. It is $1.67 \%$ in males and $1.06 \%$ in females and it is statistically significant $(P<0.05)$. But the study conducted in Paediatric Indoor Patient Department of Tertiary Care Teaching Hospital in Pune, India ${ }^{[28]}$ shows that case fatality rate was much higher in females $(1.5 \%)$ than males $(1.1 \%)$ and that was statistically significant. V. P Reddaiah et al. ${ }^{[29]}$ in their study on 'Epidemiology of pneumonia in rural less than five years reveals that female have higher case fatality rate than males. Australian Bureau of Statistics ${ }^{[30]}$ also support that case fatality rate of pneumonia is higher in females than males.

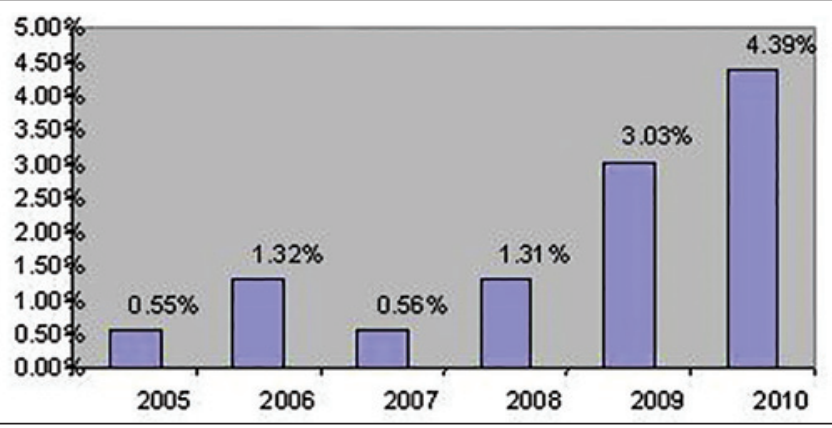

Figure 2: Trend of case fatality rate of pneumonia from 2005 to 2010

Present study shows the reduction in the infection of pneumonia from $13.13 \%$ in 2005 to $1.65 \%$ in 2010 . On the contrary to the case fatality, the present study show more case infection in low age groups and less in older age groups; it is $76.21 \%$ in $0-5$ years and $0.69 \%$ in 86 years and above. P. Rijal et al. ${ }^{[31]}$ supports these findings in their study on profile of acute lower respiratory tract infection in children at Nepal Medical college Teaching Hospital that more infection occur in low age groups.

In the present study case, infection is higher in males than in females. It is $60.77 \%$ in males and $39.22 \%$ in females. The study reports from England, Wales, Northern Ireland and Republic of Ireland ${ }^{[32]}$ supporting that case infection is higher in males than females. Choi et al. ${ }^{[33]}$ in their hospital study in Korea reveal that $68.8 \%$ of hospitalized cases are males; even though, no significant difference in death between males and females has been reported. Similar observation has been seen on a study in Maresme coast in Spain by Almirall ${ }^{[34]}$, where case infection was higher in males than females.

In the present study low age group is more prone to pneumonia infection. Studies on risk factors on infection of pneumonia reveals that the more infection in low age group is strongly linked to the factors such as malnutrition, immunity, lack of access to safe water and inadequate sanitation, lack of proper breast feeding, indoor air pollution and inadequate access to health care ${ }^{[35]}$ and these risk factors are more common in India. S Broor et al., ${ }^{[3]}$ in their study on pneumonia also revealed the similar risk factors of pneumonia like indoor air pollution, malnutrition and lack of breast feeding. Prasad D Pore et al., ${ }^{[37]}$ study on risk factors of acute respiratory infection (ARI) in 0-5 years age group in Solapur also support that immunity and nutritional status affect the respiratory diseases under five.

\section{Limitations of the study}

This is a hospital-based retrospective study. This covers only the case fatality of pneumonia and its age and sex distribution during the study period of five years. As a hospital-based study it has many limitations and this study does focus on age, sex and year but not extended over the other variables such as socio-economic status, area of residence, breast feeding or other factors related to pneumonia infection. 


\section{CONCLUSION}

The preset study reveals that low age group is the high risk group for infection; but mortality is comparatively low in this group. Even though infection is low in old age, mortality is much higher in old age groups. Considering its fatality, much emphasis should be given to the preventive measures along with early diagnosis and treatment of pneumonia to reduce the infection and consequences in all the age groups. Case infection of low age groups could be controlled by limiting the risk factors of malnutrition, lack of breast feeding and indoor pollution and other related factors.

\section{REFERENCES}

1. Jeffrey C. Pommerville. Alcamo's Fundamentals of Microbiology, $9^{\text {th }}$ ed. Jones and Bartlett Learning publishers, United States of America, 2010. p. 323.

2. Anil Kumar A, Erina Saha, Deepak Patra, Swapna Chakraborty. Out come of acute Lower Respiratory Tract Infection in Children. Ind Med Gaz 2011;10:394-9.

3. Investing in health: The world development report. Washington, DC: World Bank; 1993.

4. Pneumonia Progress Report 2012 International Vaccine Access Centre (IVAC) John Hopkins Blooberg School of Public Health November 2012. Available from: http://www.jhsph.edu/ivac. [Last accessed on 2012 Nov 12].

5. Ghimire M, Bhattacharya SK, Narain JP. Pneumonia in South East Asia Region: Public perspective. Indian J Med Res 2012;135: 459-468.

6. Available from: http://www.symptoms.in/pneumonia statistics.html [Last accessed on 2013 Nov 03]

7. Trotter CL, Stuart JM, George R, Miller E. Increasing Hospital admissions for Pneumonia, England. Emerg Infect Dis, 2008;14:727-33.

8. Fry AM, Shay DK, Holman RC, Curns AT, Anderson LJ. Trends in hospitalizations for pneumonia among persons aged 65 years or older in the United States 1988-2002. JAMA 2005;294:2712-9.

9. Hebert PL, McBean AM, Kane RL. Explaining Trends in Hospitalizations for pneumonia and Influenza in the elderly. Med Care Res Rev 2005;62:560-82.

10. Oosterheert JJ, Bonten MJ, Hak E, Lammers JW, Schneider MM, Hoepelman IM. The increase in pneumonia-related morbidity and mortality among adults in the Netherlands and possible explanations for it. Ned Tijdschr Geneeskd 2004;148:1765-9.

11. Kim SA, Kilgore PE, Lee SY, Nyambat B, Ki M. Trends in Pneumonia and Influenza associated hospitalizations in South Korea, 2002-2005. J Health Popul Nutr 2011;29:574-82.

12. Ghimire M, Bhattacharya SK, Narain JP. Pneumonia in South East Asia Region: Public Health Perspective. Indian J Med Res 2012;135:459-68.

13. Murray CJ, Lopez AD, Black R, Ahuja R, Ali SM, Baqui A, et al. Population health metrics research consortium gold standard verbal autopsy validation study: Design, implementation and development of analysis datasets. Popul Health Metr 2011;9:27.

14. Suwanjutha S, Chanasetrs R, Chantarojanasiri T, Hotrakitya S. Risk factors associated with morbidity and mortality of pneumonia in Thai children under 5 years. South East Asian J Trop Med Public Health 1994;25:606.

15. Naheed A, Saha SK, Breiman RF, Khatun F, Brooks WA, El Arifeens S, et al. Multihospital surveillance of pneumonia burden among children aged $<5$ years hospitalized for pneumonia in Bangladesh. Clin Infect Dis 2009;48 (Suppl 2):S82-9.

16. Maganga, Ellubey Rachel. Pneumonia case fatality rate in children under five. Understanding variations in district hospitals in Malawi.
Available from: http://urn.nb.no/URN:NBN:no-10357 [Last accessed on 2013 Mar 12]

17. Sehgal V, Sethi GR, Sachdev HP, Satyanarayana L. Predictors of Mortality in subjects hospitalized with acute lower respiratory tract infections. Indian Paediatr 1997;34;213-9.

18. Agarwal PB, Shendumikar N, Shastia NJ. Host factors and Pneumonia in hospitalized children. J Indian Med Assoc 1995;93:271-2.

19. World Health Organization. Pneumonia. Fact sheet No. 331. April 2013. http://www.who.int/mediacentre/factsheets/fs331/en/.

20. Pneumonia behind death of Kids under five. The Times of India 12/5/2012.

21. Rudan I, Boschi-Pinto C, Biloglav Z, Mulholland K, Campbell H. Epidemiology and Etiology of Childhood Pneumonia. Bull World Health Organ 2008;86:408-16

22. Singh V, Aneja S. Pneumonia management in the developing World Paediatr Respir Rev 2011;12:52-9.

23. India tops global pneumonia child death. New Delhi: Deccan Herald Daily, Thursday 05 September, 2013; 2012.

24. Ely EW, Haponik EF. Pneumonia in the elderly. J Thorac Imaging 1991;6:45-61.

25. Marrie TJ, Carriere KC, Jin Y, Johnson DH. Factors associated with death among abults $<55$ years of age hospitalized for community acquired pneumonia. Clin Infect Dis 2003;36:413-21.

26. Mufson MA, Stanek RJ. Bacteremic Pneumococcal Pneumonia in one American city: A 20 year longitudinal study, 1978-1997. Am J Med 1999;107:S34-43.

27. Janssens JP, Krause KH. Pneumonia case fatality rate in the elderly. Lancet Infect Dis 2004;4:112-24.

28. Debnath D, Wanjpe A, Kakrani V, Singru S. Clinical and epidemiological study of acute respiratory infection cases in children below twelve years of age in a tertiary care teaching hospital Pune, India. Med J Dr DY Patil Univ 2012;5:125-8.

29. Reddaiah VP, Kapoor SK. Epidemiology of pneumonia in rural under five. Indian J Pediatr 1990;57:701-4.

30. Causes of Death, Australian Bureau of Statistics Australia, 2009. www. abs.gov.au. March 19, 2012.

31. Rijal P, Sharma A, Shrestha S, Upadhyay S. Profile of acute lower respiratory tract infection in children under fourteen years of age at Nepal medicalcollege teaching hospital. Nepal Med Coll J 2011;13:58-61.

32. Durlach R, Mcllvenny G, Newcombe RG, Reid G, Doherty L, Freuler C, et al. Prevalence Survey of health care associated infections in Argentina; comparison with England, Wales, Northern Ireland and South Africa. J Hosp Infect 2012;80:217-23.

33. Choi WI, Rho BH, Lee MY. Male predominance of pneumonia and hospitalization in pandemic influenza A (HINI) 2009 infection. BMC Res Notes 2011;4:351.

34. Almirall J, Bolibar I, Balanzo X, Gonzalex CA. Risk factors for community acquired pneumonia $n$ adults: A population based case control study. Eur Respir J 1999;13:349-55.

35. Smith KR, Samet JM, Romieu, Bruce N. Indoor air pollution in developing countries and acute lower respiratory infections in children. Thorax 2000;55:518-32.

36. Broor S, Pandey RM, Ghosh M, Maitreyi RS, Lodha R, Singhal T, et al. Risk factors for severe acute lower respiratory tract infection in under five children. Indian Paediatr 2001;38:1361-9.

37. Pore PD, Ghattargi $\mathrm{CH}$, Rayate MV. Study of risk factors of Acute Respiratory Infection (ARI) in under fives in Solapur. Natl J Community Med 2010;1:64-67.

How to cite this article: Antony J, Celine T, Chacko M. Case fatality of Pneumonia: A '5' year retrospective study. Int J Med Public Health 2014;4:163-6.

Source of Support: Nil, Conflict of Interest: None declared. 